\title{
ENERGY REHABILITATION OF VENTILATED FAÇADES USING PHENOLIC PANELLING AT THE UNIVERSITY OF ALICANTE MUSEUM: THERMAL CHARACTERISATION AND ENERGY DEMAND
}

\author{
VÍCTOR ECHARRI IRIBARREN ${ }^{1}$, ANTONIO GALIANO GARRIGÓS ${ }^{1}$ \\ \& ALMUDENA ESPINOSA FERNÁNDEZ ${ }^{2}$ \\ ${ }^{1}$ Department of Building Construction, University of Alicante, Spain \\ ${ }^{2}$ Department of Architecture, University of Zaragoza, Spain
}

\begin{abstract}
In the 1990s, phenolic panels made from Bakelite-finished wood were given a $1 \mathrm{~mm}$-thick finishing layer of natural wood, which was protected by a film of waterproof paper. The edges were protected with the same type of phenolic resins. In practice, a gradual deterioration of the protective layer occurred due to the combined action of UV rays and rainwater. When the wood lost its protective layer, it expanded, deformed and acquired whitish stains due to the action of microorganisms. The edges suffered similar deterioration processes. We present a sample of the damage at a museum. The deterioration of the panels was worsened by their incorrect positioning during construction. A type of sandwich was made, with phenolic panel on the exterior, then rock wool insulation and MDF wood panels. This was given rigidity using wooden frames. When thermal bridges occurred due to gaps in the insulation, this gave rise to differences in surface washing which worsened the outside appearance. Once a diagnosis of the damage had been arrived at, energy rehabilitation of the covering was carried out, which involved putting in new-generation phenolic panels with a non-degradable acrylic layers and edges protected using synthetic resins. These were fitted on top of the pre-existing panels using threaded rods and a $3 \mathrm{~cm}$ layer of polyurethane insulation was sprayed over the whole surface. Furthermore, air has been allowed to circulate, as in a ventilated façade. This avoids any possible continuous damp problems and at the same time, in summer, avoids heat building up due to the solar radiation. The building was monitored over a full, year-round cycle which allowed us to learn about its energy performance using Design Builder software, which had been calibrated using temperature adjustments and real energy consumption data. We present the results, which show the reduction in the building energy demand.
\end{abstract}

Keywords: energy rehabilitation, Bakelite-finished wood, monitoring, damage to buildings.

\section{INTRODUCTION}

Regulatory requirements on energy efficiency have become more extensive since implementation of the Technical Building Code (Spanish initials: CTE) in 2007 [1]. Some public buildings, mainly in the tertiary sector, have been renovated in the last decade, yielding a noticeable improvement in indoor environmental comfort and energy consumption. On many occasions, however, major design errors in the construction of public buildings in the tertiary sector, or those occupying a large surface area, has posed serious problems for energy renovation. Some of the features that create difficulties when undertaking energy-efficient refurbishment include windows that are excessively large or poorly oriented in relation to the sun, very large skylights in regions with very hot summers, or HVAC systems that are inadequate due to the type or dimensions of the building. The use of steel frame construction in pursuit of a light, precise or prefabricated structure, and often in the quest for a more environmentally friendly and sustainable building, also entails the absence of thermal inertia, which would cushion the impact of 
temperature variations on the indoor air temperature. Furthermore, these construction techniques, which are much more demanding in terms of industrial manufacture, require the application of sealants at joints; however, such materials rarely receive due maintenance, resulting in rapid deterioration and a high rate of air infiltration, with the consequent energy consumption this entails.

Here, we present a report on the renovation of the Museum of the University of Alicante (MUA), built in 2000. In previous papers, we described some of the damage the building presented, and the renovation techniques applied in 2011 [2]. We also quantified the comfort and energy efficiency performance of radiant heating, ventilation and air conditioning (HVAC) systems over the existing forced-air systems based on a heat pump [3], [4]. In this paper, we describe the renovation techniques applied to the envelope, and report the results of monitoring and of simulations performed using the Design Builder tool, which was calibrated and then employed to quantify the energy savings achieved as a result of the intervention.

\section{TECHNICAL DESCRIPTION OF THE MUA}

The building consists of an approximately $12 \mathrm{~m}$ tall prism occupying a floor area measuring $60 \times 25 \mathrm{~m}$, with a single interior space (Fig. 1). The metal structure is based on large frames transverse to the façade, without intermediate supports. It has a light deck-type roof with large skylights fitted with motorised metal blinds to provide shade. The entire perimeter of the lower part consists of $2.50 \mathrm{~m}$ high single-glazed panes, while the rest of the façade is a multilayer envelope composed of:

1. Interior panel of $16 \mathrm{~mm}$ thick lacquered MDF.

2. Rock wool blanket.

3. Frame of pine wood battens measuring $60 \times 60 \mathrm{~mm}$ in section.

4. $6 \mathrm{~cm}$ thick rock wool blanket.

5. Exterior panel of resin-coated wood measuring $2440 \times 1220 \mathrm{~mm}$ and $13 \mathrm{~mm}$ thick.

The envelope was a sandwich structure, in which the phenolic panels and the MDF were anchored to a wooden frame and the spaces in between were filled with rock wool. Insulation of the façade was therefore discontinuous and there were thermal bridges (Fig. 2).

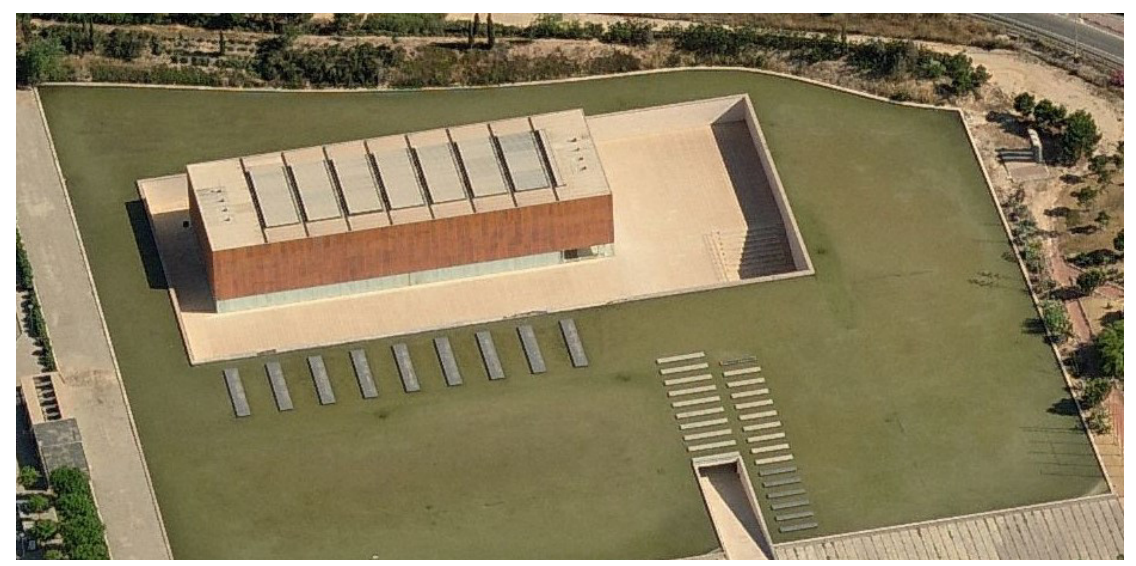

Figure 1: Aerial view of the building, surrounded by an artificial lake. 




\begin{tabular}{|c|c|}
\hline \multicolumn{2}{|c|}{ DETAIL LEGEND } \\
\hline 01 & $\begin{array}{l}\text { Facing } \\
\text { Bakelized wood board }\end{array}$ \\
\hline 02 & $\begin{array}{l}\text { Thermal Isolation } \\
\text { Rock Wool }\end{array}$ \\
\hline 03 & $\begin{array}{l}\text { Inside estructure } \\
\text { Wood upright }\end{array}$ \\
\hline 04 & Elastic seal \\
\hline 05 & $\begin{array}{l}\text { Rear facing } \\
\text { Agglomerate wood }\end{array}$ \\
\hline 06 & $\begin{array}{l}\text { Outside structure } \\
\text { Metal upright }\end{array}$ \\
\hline 07 & $\begin{array}{l}\text { Seal tap } \\
\text { Bakelized wood }\end{array}$ \\
\hline 08 & Seal background \\
\hline
\end{tabular}

Figure 2: Section of the external envelope. Original project.

\section{DESCRIPTION OF THE DAMAGE}

Simple observation of the resin-coated panels revealed a general deterioration. Lack of accessibility hindered examination of the condition of some elements. Consequently, we took some samples (Fig. 3). The damage detected on the façade was as follows:

1. Staining on the panels corresponding to the subframe onto which they were mounted. Darkening on the south and west façades.

2. Warping on the exterior resin-coated panels.

3. Absence or disintegration of sealant seams. Peeling and cracking of joints between boards. Water penetration of the sandwich via these joints.

4. Drip marks and irregular stains on parts of the north and east façades.

5. Hazy white stains, more pronounced at the edges.

6. Fungal colonies on the inner surface of the façade, on the MDF panel.

7. Piecemeal repair of screws. The coating had lost its elastic properties, and was discoloured and flaking.

8. Some glass in the lower façade was cracked due to deterioration of the sealant.

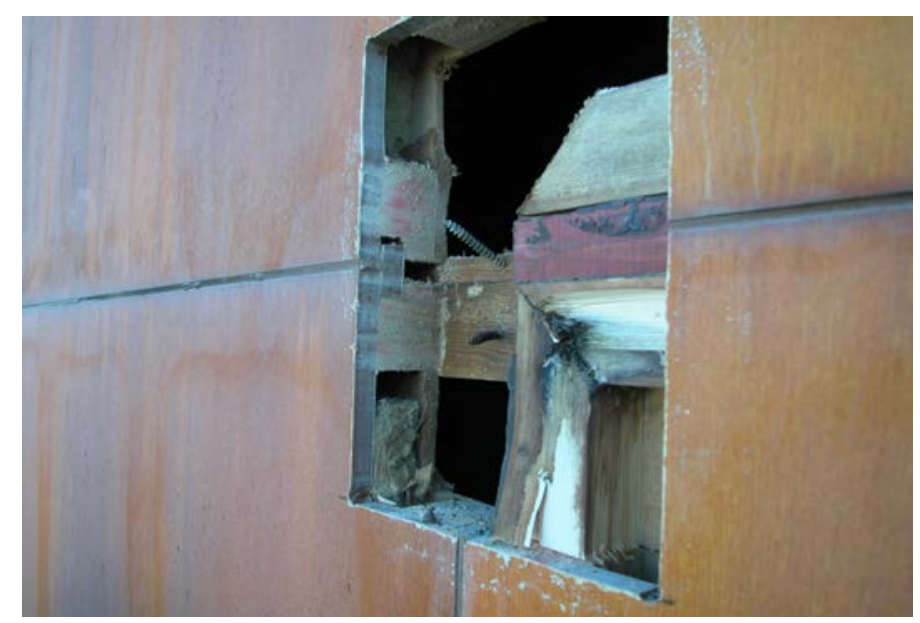

Figure 3: Aspect of the samples taken from the main façade. 
Besides being the result of insufficient protection of the first-generation resin-coated wood panels, the general deterioration of the façade also bore a direct relationship to the original construction system. Several degradation processes had occurred simultaneously. The main factor that had accelerated the process was the absence of sealing at the panel joints, due to insufficient thickness, lack of initial adhesion and weathering at the joints and panel edges. Rain had penetrated the sandwich panel and the moisture was retained due to lack of natural ventilation, causing the damage described. The process of deterioration and its causes has been described in previous publications [2].

\section{INTERVENTION PROJECT: ENERGY RENOVATION}

The goal of renovating the façade was to restore its aesthetic and functional properties by ensuring complete impermeability and increased thermal insulation without the thermal bridges caused by the wooden batten subframe.

The existing panels were maintained for economic reasons, and a new wooden subframe was added, anchored by rods screwed into the existing metal structure. Polyurethane foam was sprayed continuously over the entire surface, and latest generation resin-coated wood panels [5] were mounted onto galvanized steel elements anchored onto the wooden battens, thus creating a double-skin façade [6] without seals between panels (Fig. 4). Below, we describe the interventions in the order they were implemented (Figs 5 and 6):

1. The original boards were preserved, and these served to anchor the new subframe supporting the new layers of the repaired façade.

2. A subframe of galvanized $40 \times 40 \mathrm{~mm}$ steel tubes was mounted onto these panels, and attached to the existing metal structure by means of galvanized threaded steel rods.

3. Then, a structure consisting of $60 \times 50 \mathrm{~mm}$ galvanized steel $\mathrm{H}$ beam uprights measuring $60 \times 50 \mathrm{~mm}$ and placed $60 \mathrm{~cm}$ apart was screwed onto these battens (Figure 5). A band of neoprene was placed at the anchor points to prevent thermal bridges.

4. The $\mathrm{H}$ beams were protected with a polyethylene film and adhesive tape.

5. Then, the entire surface was sprayed with polyurethane foam to a mean depth of $3 \mathrm{~cm}$. The polyurethane serves as thermal insulation and render the boards waterproof.


Figure 4: Section of the external envelope. Intervention project. 

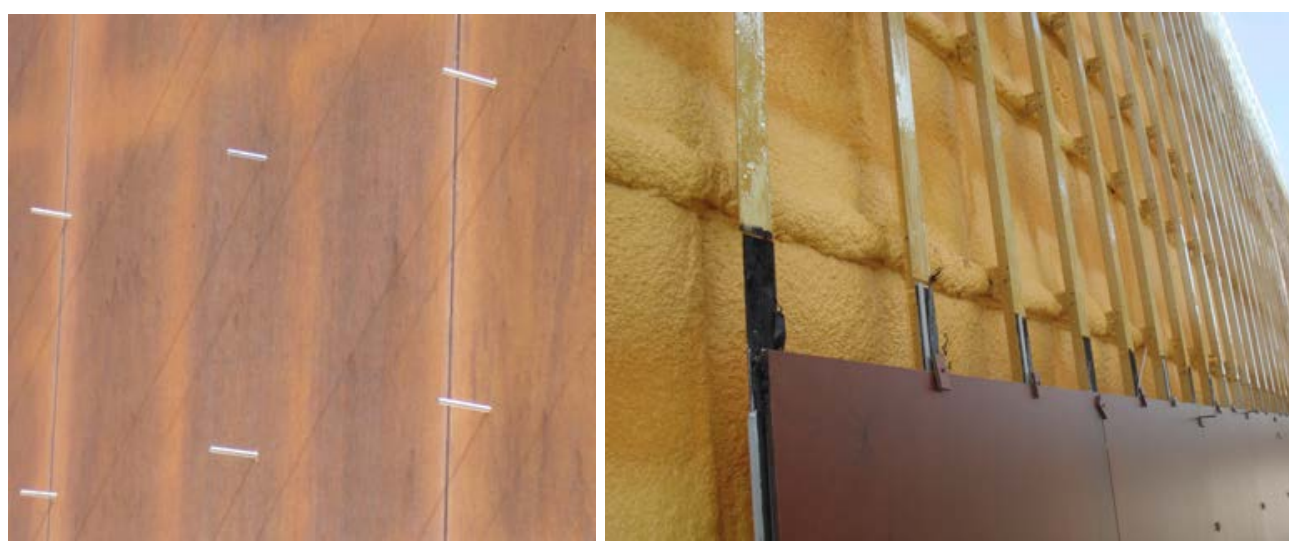

Figure 5: Execution phases of the new envelope mounted over the existing one.

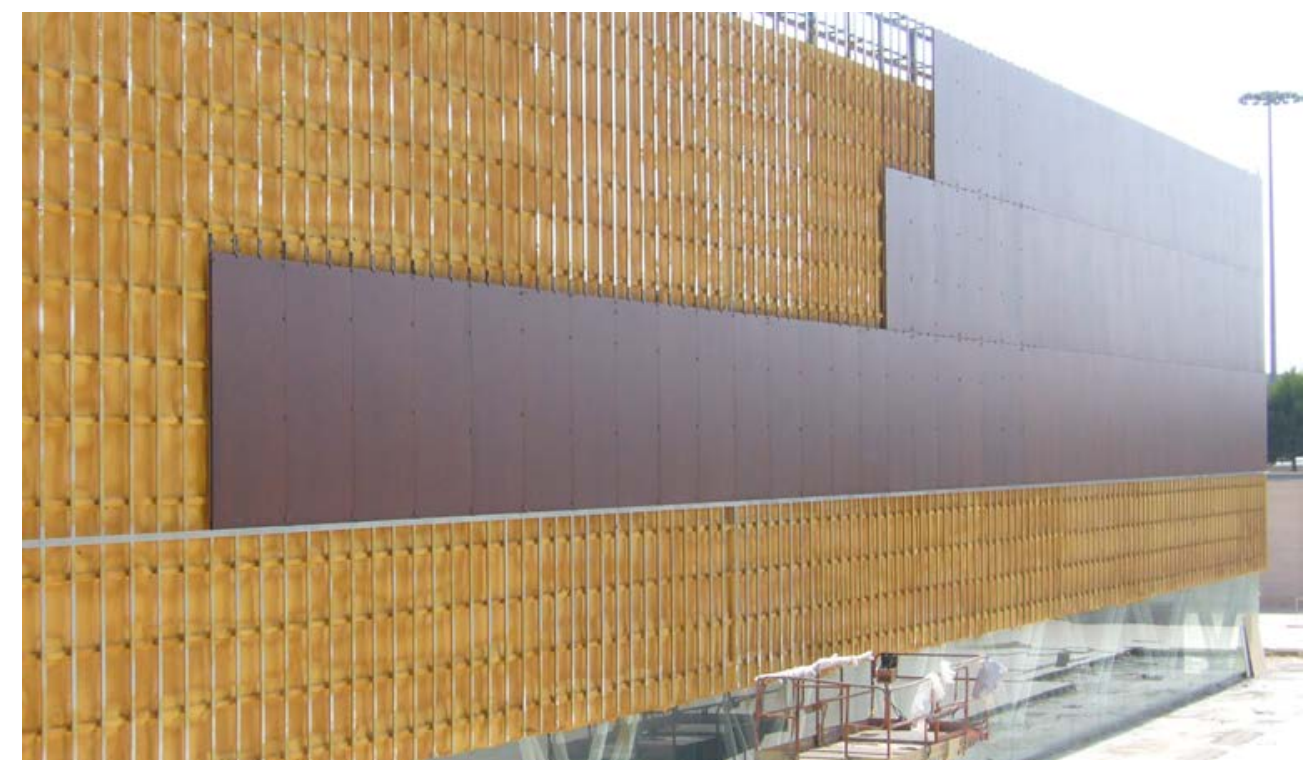

Figure 6: Placement of panels mounted onto a galvanized steel subframe.

Once the adhesive tape had been peeled off the metal uprights, the elements to be joined were cleaned. Subsequently, latest generation resin-coated wood panels measuring $2.440 \times$ $1.220 \mathrm{~mm}$ and $13 \mathrm{~mm}$ thick were mounted onto the uprights using a structural monocomponent polyurethane adhesive, reinforced with double-sided adhesive tape to stabilise them while the polyurethane adhesive was drying (Figs 6 and 7). 

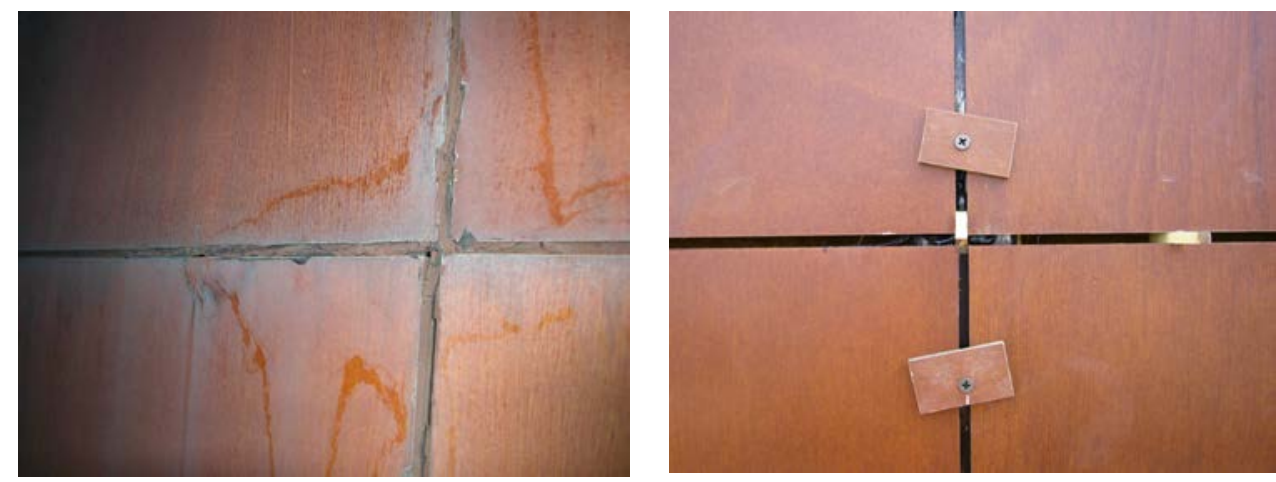

Figure 7: Details of the old and new phenolic panels.

\section{MONITORING THE MUA}

The MUA was monitored over the full course of 2014, using a wireless system incorporating more than 30 sensors to measure temperature and relative humidity, as well as a pyranometer. The temperature sensors were connected to EL-WiFi-TC thermocouple probe data loggers (Figs 8 and 9). EL-WiFi-TH temperature and humidity data loggers (Fig. 8), with built-in temperature and relative humidity sensors, interpreted the recorded data and sent signals wirelessly to a RouterOS router, connected to a laptop (Fig. 9). EasyLog WiFi Software was used to receive and store data on the computer. The data were then sent every day to a virtual disc, and a password gave online access to the information from any computer. In addition, a small station was installed with outside air temperature and relative humidity sensors, and a pyranometer to measure solar radiation.



Figure 8: Temperature and humidity sensors and EL-WiFi-TC and TH data loggers. 


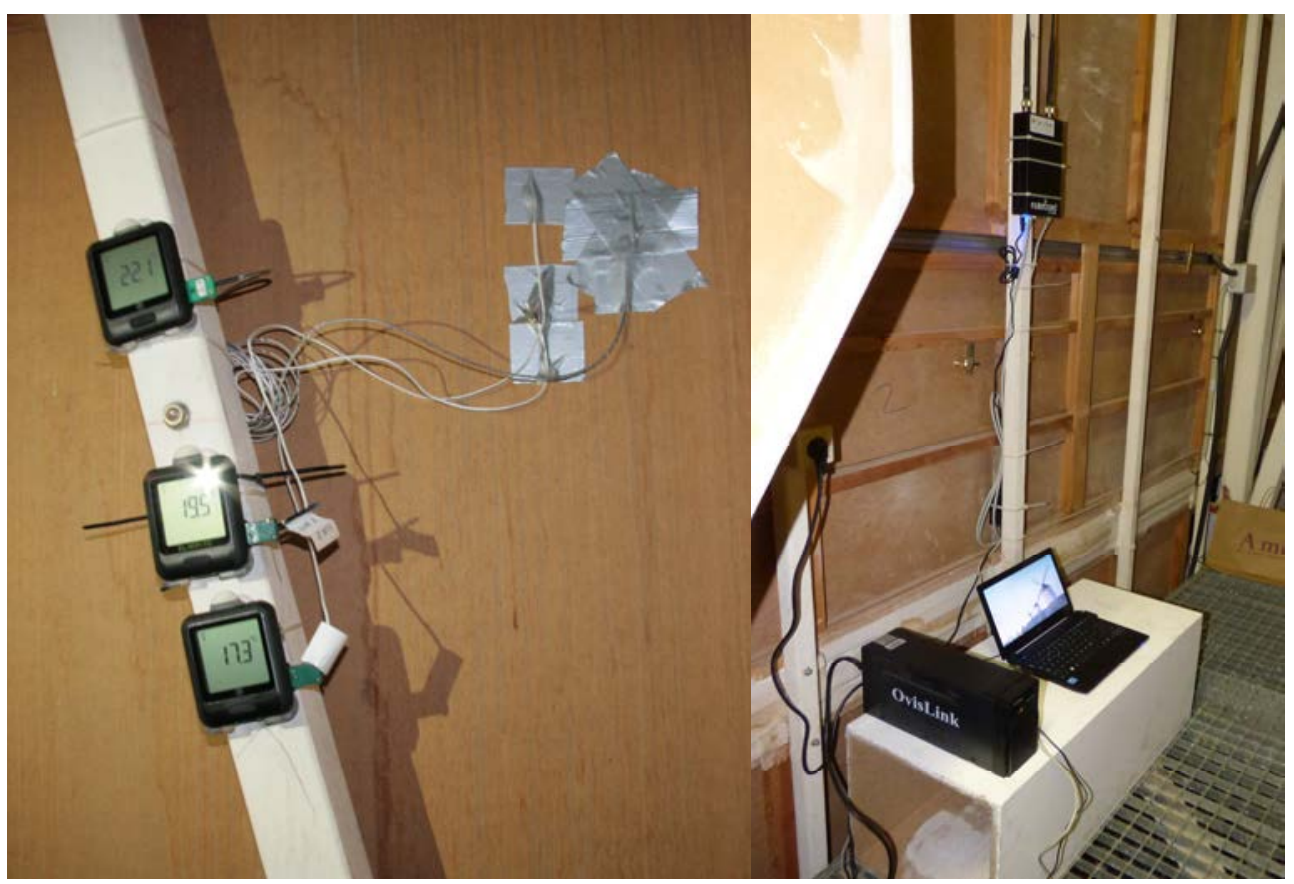

Figure 9: EL-WiFi-TH temperature and humidity data loggers and RouterOS router.

To fit the parameters obtained from simulation to real data, or calibrate the model, we used the climate file obtained in situ corrected with values for climatological data recorded by the weather station owned by the Climatology Laboratory at the University of Alicante. The air infiltration value was corrected to fit the annual energy demand obtained versus actual energy consumption data provided by the Department of Campus and Sustainability at the University of Alicante. Mean energy consumption for the period 2010-2014 was $203,050 \mathrm{kWh} / \mathrm{a}$. After subtracting the value for lighting consumption, $2.8 \mathrm{kWh} / \mathrm{m}^{2} \mathrm{a}$, we obtained a value of 197.5 MWh/a for the existing air-based HVAC system. The same was done to fit the interior surface temperatures and indoor air temperature. The use of setpoint temperatures of $20^{\circ} \mathrm{C}$ in winter and $24^{\circ} \mathrm{C}$ in summer, from 9:00 h until 20:00 h, together with the fact that users could not individually adjust the system, facilitated the calibration process.

\section{CALCULATION OF ENERGY DEMAND FOR THE MUA}

To simulate the building's performance in terms of energy demand and interior comfort parameters, the following data were entered into the Design Builder tool. Winter was defined as encompassing the period from December 1 to April 30, and summer from May 1 to November 30. This is the protocol established by the UA, tailored to normal weather conditions in San Vicente del Raspeig. Hours of operation were from 9:00 h to 20:00 h. Setpoint temperatures for indoor air were $20^{\circ} \mathrm{C}$ in winter and $24^{\circ} \mathrm{C}$ in summer. Occupation, for standard calculation of air renewal, was 709 people, i.e. 0.5 people per $\mathrm{m}^{2} .12 .5$ litres of air must be renewed per second per person, equivalent to $2.5 \mathrm{ren} / \mathrm{h}$. Air infiltration through the envelope was moderate thanks to the application of polyurethane foam during renovation of the phenolic panels. The initial air renewal value considered was $0.7 \mathrm{ren} / \mathrm{h}$, 
which was subsequently adjusted in the calibration phase. Lighting had a power of $4.82 \mathrm{~kW}$. The large skylights were considered with the interior aluminium blinds completely closed to the passage of solar radiation, as was habitual. The glass envelope around the lower part of the building was protected by continuous MDF panels placed 1.40 $\mathrm{m}$ away, to prevent direct solar radiation indoors.

To thermally characterise the envelopes [7], the thermal transmittance values $U$ of the envelopes were obtained in situ according to the thermal conductivity values given in the TBC database [8]. Thermal bridges were also quantified [9] using the AnTherm simulation tool (Figs 10-12). Values were obtained for the coupling coefficient $L^{2 D}$ and linear thermal transmittance $\Psi$ of the thermal bridges in MUA 1 and MUA 2 (Table 1). A 43\% reduction in transmittance was obtained at the façade-roof point of union, and a $32 \%$ reduction in the same at the thermal bridges created by the wooden frame [3]. Figs 10-12 show the thermal gradients where the walls meet the roof and the mezzanines $1.4 \mathrm{~m}$ wide, for MUA 1 and MUA 2.
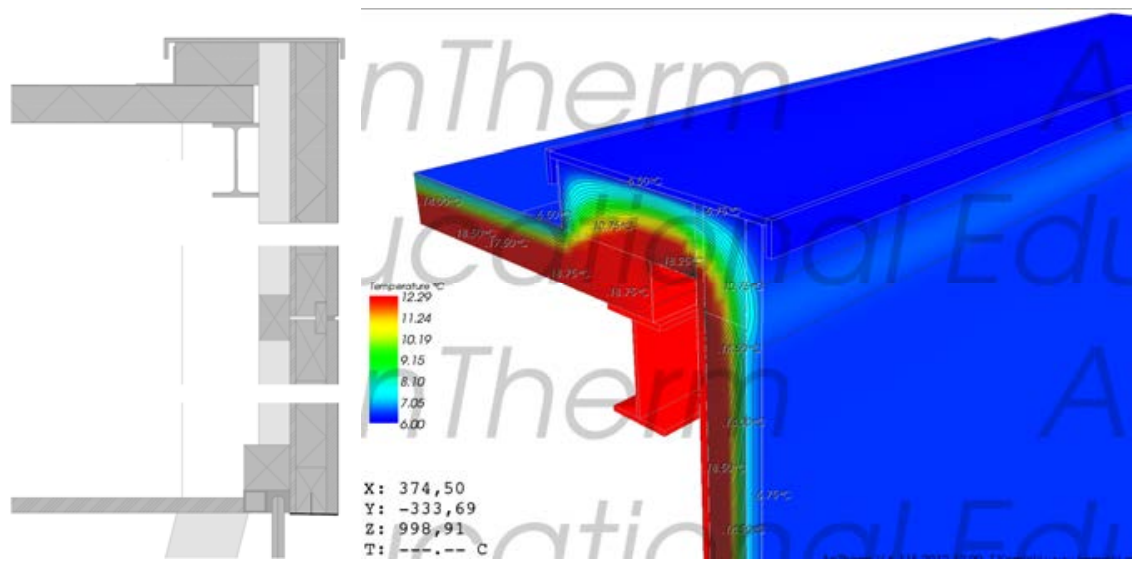

Figure 10: Temperature gradient. Façade-roof point of union. AnTherm.
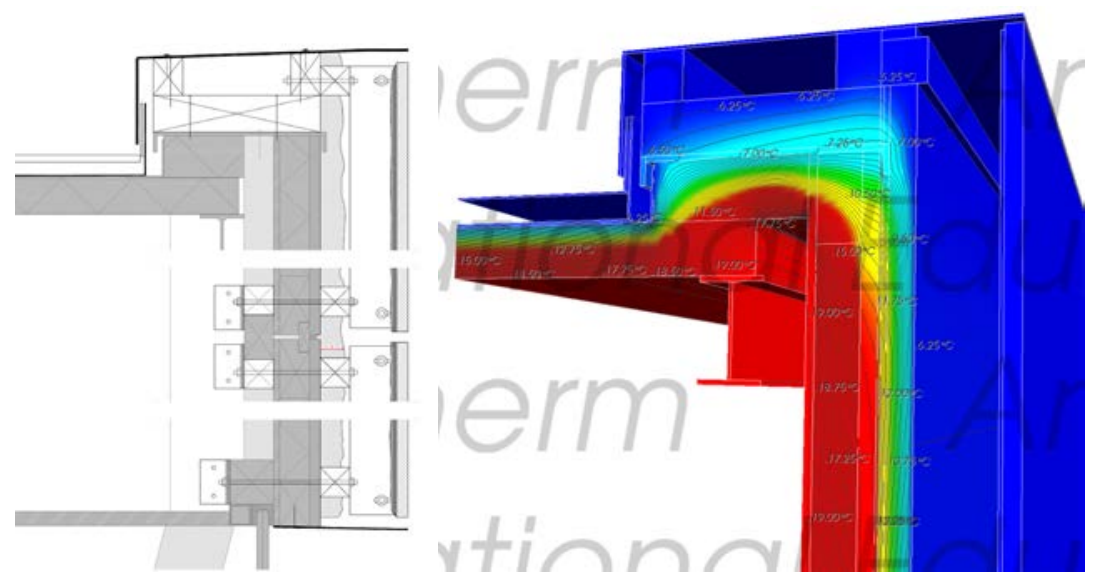

Figure 11: Temperature gradient after the intervention project. Thermal bridge. AnTherm. 


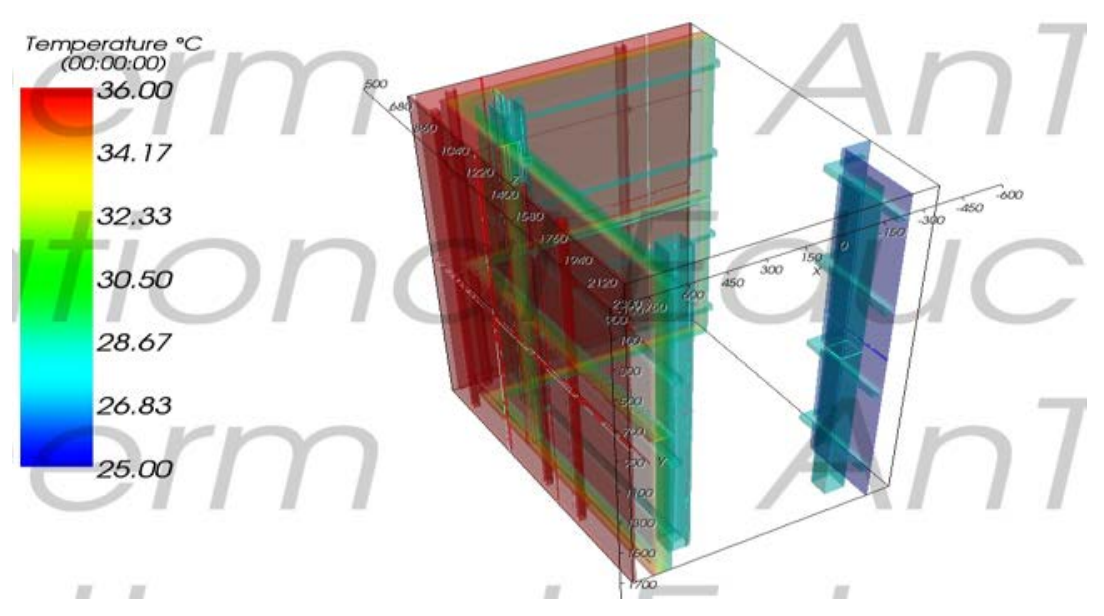

Figure 12: Temperature gradient. Double skin of the mezzanines. AnTherm.

Table 1: Thermal transmittance values $U$ and $\Psi$ for MUA 1 and MUA 2.

\begin{tabular}{lcccccc}
\hline & \multicolumn{3}{c}{ Envelope } & \multicolumn{3}{c}{ Envelope-roof point of union } \\
\hline & $U \mathrm{w} / \mathrm{m}^{2} \mathrm{k}$ & $L^{2 D}$ & $\Psi_{\mathrm{w} / \mathrm{mk}}$ & $U \mathrm{w} / \mathrm{m}^{2} \mathrm{k}$ & $L^{2 D}$ & $\Psi_{\mathrm{w} / \mathrm{mk}}$ \\
\hline MUA 1 (2000) & 0.794 & 1.324 & 0.228 & 0.794 & 1.334 & 0.177 \\
\hline MUA 2 (2010) & 0.452 & 0.754 & 0.130 & 0.452 & 0.915 & 0.149 \\
\hline
\end{tabular}

Once the thermal bridges had been quantified, we simulated the performance of the MUA using the Design Builder tool (Fig. 13) in order to compare energy demands in summer and winter and quantify the energy savings achieved through renovation. To fit the parameters obtained from simulation to real data, or calibrate the model, we used the values for indoor air and retaining wall temperatures obtained from monitoring MUA 2. We also entered the climate file for outside air temperature and relative humidity, and solar radiation levels as measured by a pyranometer, obtained in Alicante in previous studies [4]. The surface temperature of the walls was corrected up to the value obtained by monitoring, and the value of infiltration was adjusted to $1.15 \mathrm{ren} / \mathrm{h}$.

Figs 14-16 show the temperature gradients produced in a simulation of the different spaces at different times of day and days of the year. Table 2 shows the results of thermal loads and energy losses with a breakdown by elements. The thermal contribution in winter from lighting, equipment, occupation and solar gain was not taken into account. As is clear from the results given in Table 3, renovation of the envelope has yielded a $15 \%$ reduction in HVAC energy. The combination of better insulation and a significant reduction in air infiltration levels has been decisive [10]. Nonetheless, energy consumption is still too high. The use of a glass wall around the lower part of the building combined with skylights in the roof (even though these have blinds) constitutes an unsatisfactory design in terms of energy efficiency. Bioclimatic techniques should have been employed [11], or at least the amount of glass should have been drastically reduced, since museums require stringent indoor temperature control. Furthermore, an analysis should have been conducted of the life cycle analysis (LCA) [12] when selecting the resin-coated wood panels and glass walls, in order to predict the impact on energy consumption once occupied and the foreseeable deterioration of the phenolic panels due to poor construction design [13]. 


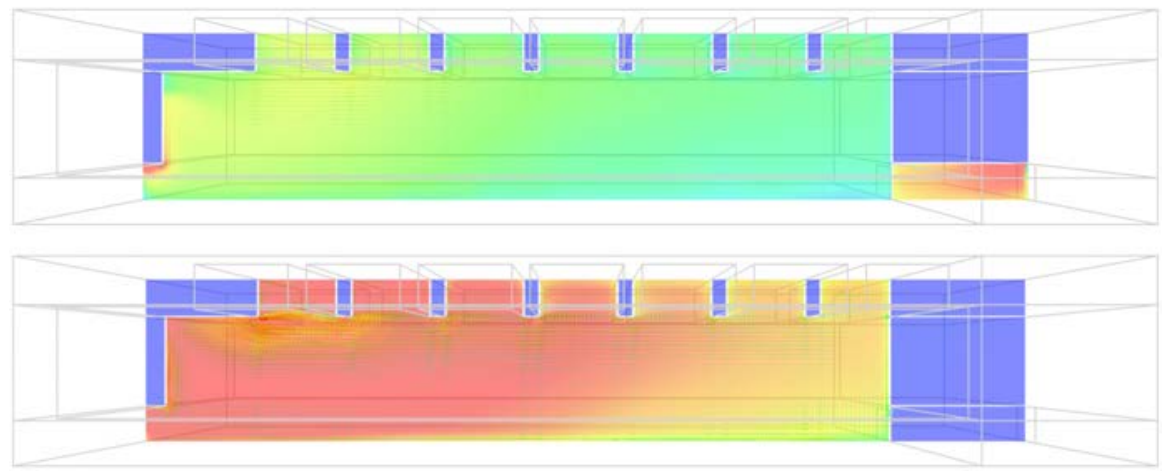

Figure 13: Modelling with Design Builder. Longitudinal sections.

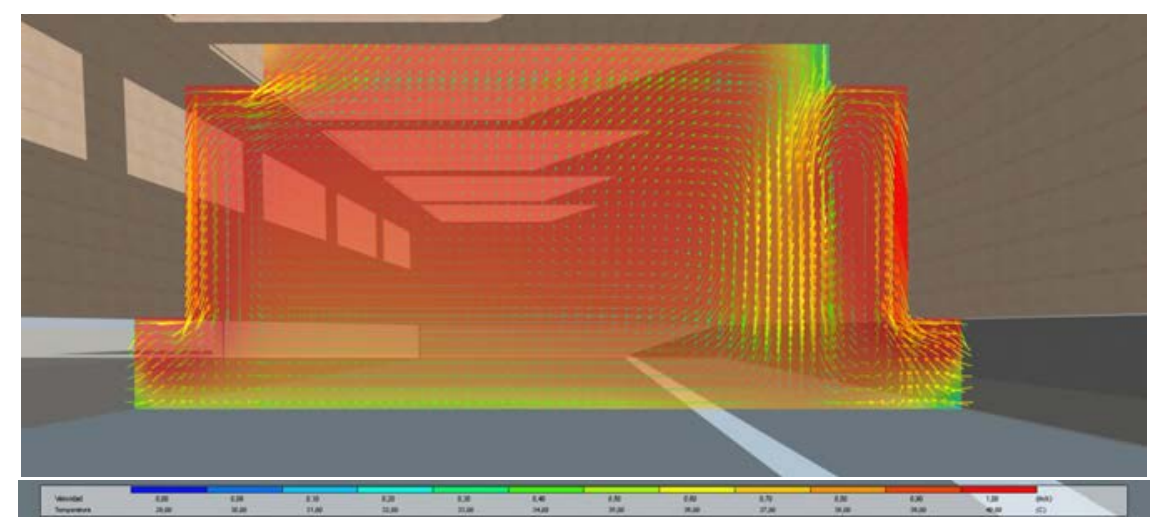

Figure 14: Cross section. Temperatures July 31 at 15:00 h.

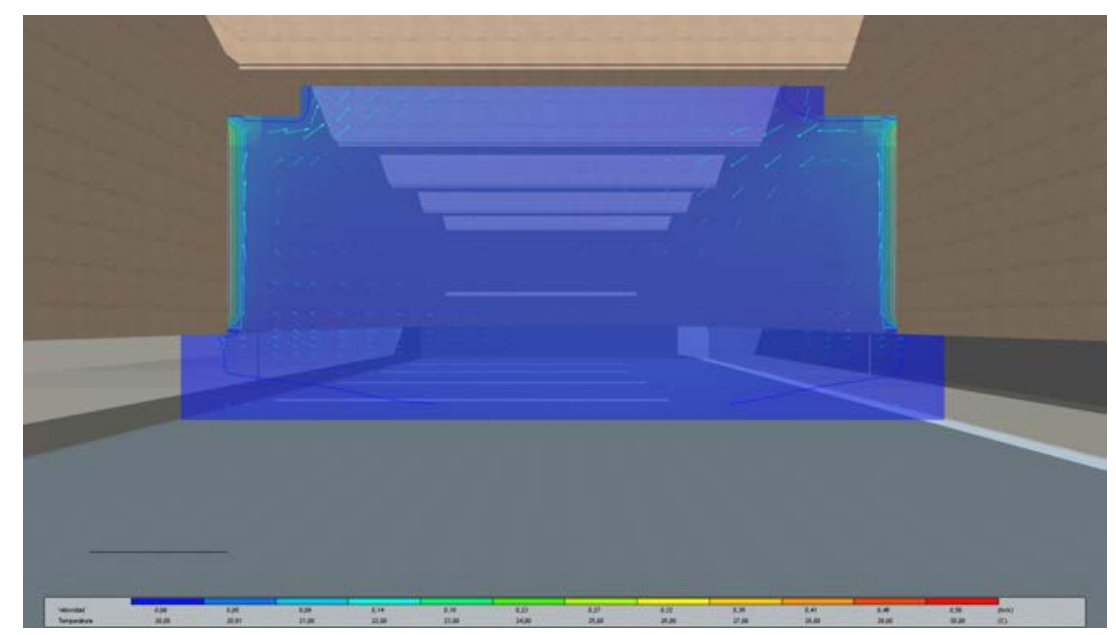

Figure 15: Cross section. Temperatures January 31 at 7:00 pm. 


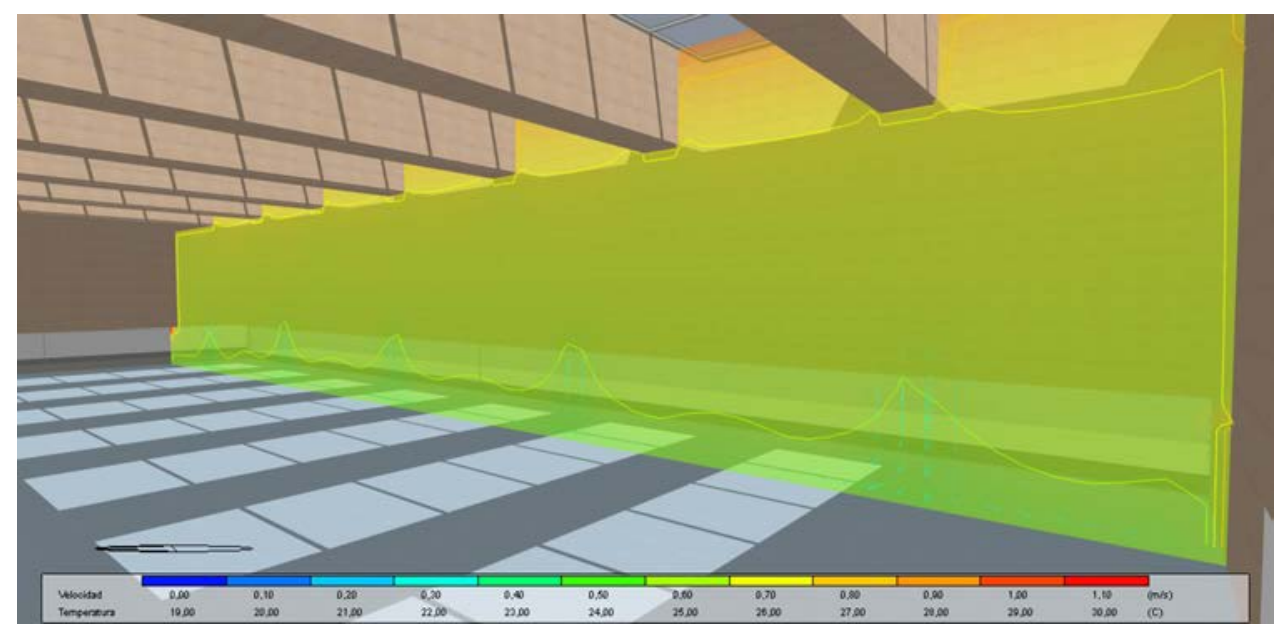

Figure 16: Cross section. Temperatures July 31 at 15:00 h.

Table 2: Calculation of energy demands before and after renovation.

\begin{tabular}{lcccc}
\hline & \multicolumn{2}{c}{ OP-1 MUA 2000 } & \multicolumn{2}{c}{ OP-2 RENOVATED } \\
\hline & SUMMER & WINTER & SUMMER & WINTER \\
\hline BUILDING ENVELOPE & $\mathrm{Wh} / \mathrm{m}^{2}$ & $\mathrm{Wh} / \mathrm{m}^{2}$ & $\mathrm{Wh} / \mathrm{m}^{2}$ & $\mathrm{Wh} / \mathrm{m}^{2}$ \\
\hline Glazing & & & & \\
\hline Walls & 10.733 & 10.901 & 10.723 & 10.341 \\
\hline Indoor floors & 1.689 & 216 & 814 & 251 \\
\hline Partitions & -1.506 & 6.367 & -1.403 & 7.002 \\
\hline Roof & 0 & 0 & 0 & 0 \\
\hline Exterior ground & 5.279 & 3.115 & 2.452 & 1.835 \\
\hline Infiltration & 310 & 167 & 296 & 138 \\
\hline & 12.193 & 21.532 & 3.214 & 13.331 \\
\hline LOADS & 26.119 & 41.043 & 13.268 & 33.685 \\
\hline Lighting & & & & \\
\hline Equipment & 2.414 & 2.833 & 2.414 & 2.833 \\
\hline Occupation & 3.766 & 2.658 & 3.766 & 2.658 \\
\hline Solar gains & 8.950 & 6.975 & 8.956 & 6.933 \\
\hline & 48.541 & 25.637 & 48.541 & 25.637 \\
\hline Total primary energy & 63.671 & 38.103 & 63.677 & 38.061 \\
\hline & $\mathbf{8 W h} / \mathrm{m}^{2} \mathrm{a}$ & $\mathrm{kWh} / \mathrm{m}^{2} \mathrm{a}$ & $\mathrm{kWh} / \mathrm{m}^{2} \mathrm{a}$ & $\mathrm{kWh} / \mathrm{m}^{2} \mathrm{a}$ \\
\hline & & $\mathbf{4 1 . 0 4}$ & $\mathbf{7 6 . 9 4}$ & $\mathbf{3 3 . 6 8}$ \\
\hline & & & & \\
\hline & & & & \\
\hline & & & & \\
\hline
\end{tabular}


Table 3: Calculation of energy demands before and after renovation.

\begin{tabular}{lcc}
\hline & OP $\mathbf{1}$ & OP 2 \\
\hline Energy demand in summer $\mathrm{kWh} / \mathrm{m}^{2}$ & 89.79 & 76.94 \\
\hline Energy demand in winter $\mathrm{kWh} / \mathrm{m}^{2}$ & 41.04 & 33.68 \\
\hline Annual energy demand $\mathrm{kWh} / \mathrm{m}^{2} \mathrm{a}$ & 130.83 & 110.62 \\
\hline Annual $\mathrm{CO}_{2}$ emissions during occupation & $262.968 \mathrm{~kg}$ & $222.346 \mathrm{~kg}$ \\
\hline Percentage & $\mathbf{1 0 0 \%}$ & $\mathbf{8 4 . 4 5 \%}$ \\
\hline
\end{tabular}

\section{CONCLUSIONS}

Envelope repair projects could and should be used, when necessary, as an opportunity to undertake building energy renovation. In the case of façades and light roofs, the possibility of adding new layers to existing envelopes without increasing sections of structural elements or adding reinforcements, ensures easily implemented, low-cost interventions and prevents the generation of construction and demolition waste. In the case of the Museum of the University of Alicante, it was necessary to replace the resin-coated wood panels barely 10 years after construction, due to significant deterioration. Following an analysis of the damage, it was concluded that the panels had been mounted without due care and attention. Since these were sandwich panels, they retained moisture inside, which was not subsequently eliminated by evaporation. The new intervention maintained the existing envelope, but mounted a new galvanized steel subframe over the old one, and this was then clad with latest generation phenolic panels, while the damaged panels were sprayed with 3 $\mathrm{cm}$ of polyurethane foam. This created a double-skin façade that enabled evaporation of moisture while dissipating heat in summer. Continuous polyurethane insulation mitigated the effect of thermal bridges, reducing thermal linear transmittances $\Psi$ by $32 \%$. The transmittances $U$ of walls and roofs were reduced by $43 \%$. The Design Builder tool was used to model the building. A wireless monitoring system provided data on temperature, humidity, etc. throughout a full year. The model was calibrated using the value for HVAC energy consumption (197.5 MWh/a), obtained from a meter, and a value for the thermal bridges. We also obtained a mean value for air infiltration of $1.15 \mathrm{ren} / \mathrm{h}$. This yielded a value for the building's annual energy demand. Compared with value of $130.83 \mathrm{kWh} / \mathrm{m}^{2} \mathrm{a}$, following the intervention, the building consumes $110.62 \mathrm{kWh} / \mathrm{m}^{2} \mathrm{a}$, representing an energy saving of $15.6 \%$.

Such interventions could be applied to modern heritage buildings. In addition to the Bakelited-finished wood could be used porcelain stoneware $9 \mathrm{~mm}$ or $3+3 \mathrm{~mm}$ thick, in large format, incorporating any colour, texture or image into the ceramic. In moderate coastal climates, it would provide the shell with greater protection against moisture, would dissipate the heat generated by solar radiation in summer through the ventilated chamber, and would entail a significant reduction in annual energy demand.

\section{REFERENCES}

[1] Código Técnico de la Edificación (CTE), Reglamento de Instalaciones Térmicas en los Edificios (RITE), ITC, 02.2.1.

[2] Echarri, V., Salvador, M., Ramírez, G. \& Espinosa, A., Lesiones en Paneles Fenólicos de Madera Baquelizada: Diagnóstico e Intervención. Proceedings. of $4^{\circ}$ Congreso de Patología y Rehabilitación de Edificios (PATORREB), Santiago de Compostela, Feb. 2012, ed. Colegio Oficial de Arquitectos de Galicia, p. 206, 2012. 
[3] Echarri, V., Galiano, A., Pérez, M.I. \& González, A.B., Conditioning systems by radiant surfaces: comparative analysis of thermal ceramic panels versus the conventional systems in a museum. WIT Transactions on Engineering Sciences, 83, 2014.

[4] Echarri Iribarren, V., Galiano Garrigós, A.L. \& González Avilés, A.B., Ceramics and healthy heating and cooling systems: thermal ceramic panels in buildings. Conditions of comfort and energy demand versus convective systems. Informes de la Construcción, 68(544), pp. 19-32, 2016.

[5] Singh, B., Gupta, M. \& Tarannum, H., Jute sandwich composite panels for building applications. Journal of Biobased Materials and Bioenergy, 4, pp. 397-407, 2010.

[6] Silva, G., Bengochea, M.A., Guaita, L., Segarra C. \& Corrales, J., Energy efficiency of ventilated façades with near infrared range reflective ceramic tiles. Informes de la Construcción, 68(544), pp. 5-18, 2016.

[7] Sala Lizarraga, J.M., Transmisión de calor en edificios. Arquitectura Ecoeficiente (Vol. I, Chap. 2), eds R. Hernández et al., Servicio Editorial de la UPV/ EHU: San Sebastián, 2012.

[8] UNE EN ISO 13786 Thermal performance of building products and components. Dynamic thermal characteristics. Calculation methods.

[9] Wang, S. \& Youming, C., A simple procedure for calculating thermal response factors and conduction transfer functions of multilayer walls. Applied Thermal Engineering, 22, pp. 333-338, 2002.

[10] Yeang, K., Ecodesign. A Manual for Ecological Design, John Wiley \& Sons, Ltd: London, p. 415, 2006.

[11] Bedoya, C. \& Neila, J., Técnicas arquitectónicas y constructivas de Acondicionamiento ambiental, Ediciones Munilla-Lería: Madrid, 1997.

[12] Assiego, R., et al., A decission-making LCA for energy refurbishment of buildings. Conditions of comfort. Energy and Buildings, 70, pp 333-342, 2014.

[13] Oregi, X., Hernández, P., Gazulla, C. \& Isasa, M., Integrating simplified and full life cycle approaches in decision making for building energy refurbishment: Benefits and barriers. Buildings, 5(2), pp. 354-380, 2015. 